\title{
INTRODUCING SCHOOL-BASED TEACHER-LED ASSESSMENTS IN THE IRISH SCHOOL CONTEXT: CHALLENGING THE PRACTICE OF FAVOURING CENTRALIZED, EXTERNALLY-CONDUCTED ASSESSMENT
}

La introducción de evaluaciones dirigidas por el profesorado en el contexto escolar irlandés: enfrentándose a la primacía de las evaluaciones externas centralizadas

A introdução das avaliações promovidas pelos professores no contexto escolar irlandês: enfrentando-se a primazia das avaliações externas centralizadas

\section{Ann MacPhail (1)}

John Halbert (2)

Hal O’Neill (3)

(1) University of Limerick, Ireland. Telephone: +353 (0)61234155. E-mail:

Ann.MacPhail@ul.ie

(2) National Council for Curriculum and Assessment, Dublin. E-mail:

John.Halbert@ncca.ie

(3) National Council for Curriculum and Assessment (Retired); E-mail:

halsoneill@gmail.com

\begin{abstract}
The discussion in Ireland around post-primary teachers (catering for students aged between 12- and 18-years of age) being responsible for assessing their own students' work continues. The Junior Cycle Reform (covering the first three years of post-primary education) is concerned with making fundamental changes in approaches to learning, teaching, curriculum and assessment, with school-based assessment as an important element of the reform. This presentation maps and discusses the area of mediation of assessment policy in a changing and contested assessment environment in the Republic of Ireland. To do this, the presentation tells the story of assessment in junior cycle. The story evolves as one in which government policy was intent on promoting a teacherlead, learning-oriented assessment practice which was actively resisted by the Irish postprimary teacher unions through their insistence that a centralized, externally-conducted Introducing school-based teacher-led assessments in the Irish school context: challenging the practice of favouring centralized, externally-conducted assessment
\end{abstract}


assessment at the earlier stages of post-primary education was preferable to schoolbased, teacher-led assessments.

Keywords: school-based assessment; junior cycle; Ireland; assessment policy; examinations

\section{Resumen}

En Irlanda continúa presente la discusión sobre si los profesores de Educación Secundaria (con alumnos entre 12 y 18 años) son los responsables de evaluar el trabajo de sus propios estudiantes. La Junior Cycle Reform, que abarca los tres primeros años de Educación Secundaria, incluye cambios fundamentales en los enfoques del aprendizaje, la enseñanza, el currículo y la evaluación, siendo un elemento importante de la reforma la evaluación en los propios centros. En esta presentación se describe y discute el ámbito de la mediación en las políticas de evaluación, en un entorno - el de la evaluación - cambiante y controvertido en la República de Irlanda. Para ello la presentación narra la historia de la evaluación en los primeros cursos de la Educación Secundaria. El relato continúa con el empeño del gobierno en promover prácticas evaluadoras orientadas al aprendizaje y dirigidas por los docentes, a las que se resistieron activamente los sindicatos irlandeses de Educación Secundaria, que insistían en que una evaluación centralizada y externa en los primeros años de esta etapa era preferible a las evaluaciones realizadas en los centros y dirigidas por los docentes.

Palabras clave: evaluación desde la escuela; ciclo juvenil; Irlanda; política de evaluación, exámenes

\section{Resumo}

Na Irlanda, existe um debate aberto e controverso sobre se professores da etapa pósprimária (estudantes entre os 12 e os 18 anos de idade) são ou não os responsáveis pela avaliação do trabalho dos seus próprios estudantes. Atualmente, é a Reforma do Ciclo Juvenil, que abrange os três primeiros anos da educação pós-primária que define a política educativa e que se encarrega de fazer as mudanças fundamentais, dando enfoque na aprendizagem, no ensino, no currículo e na avaliação, tendo como elemento importante a avaliação pelas próprias escolas. Nesta apresentação, descreve-se o âmbito da alteração da política da avaliação na República da Irlanda e as suas controvérsias. A pesquisa narra a história da avaliação do ciclo juvenil. A política governamental estava Introducing school-based teacher-led assessments in the Irish school context: challenging the practice of favouring centralized, externally-conducted assessment 
orientada para promover práticas de avaliação dirigida pelos docentes e orientadas pela aprendizagem, o que levou a resistências por parte dos sindicatos irlandeses de ensino pós-primário, que insistiram numa avaliação centralizada e externa, nos primeiros anos da escolaridade pós-primária, pois era melhor do que as avaliações realizadas pelas escolas e dirigidas pelos professores.

Palavras-chave: avaliação na escola; ciclo juvenil; Irlanda; política de avaliação; exames

\section{Introducción}

In a paper published in 2006, Anne Looney, then Chief Executive of the National Council for Curriculum and Assessment (NCCA), noted that assessment reform in Ireland's post-primary schools (students aged between 12- and 18-years of age) was marked by a silence 'filled with the deafening noise of two formal public examinations, which, despite the efforts of the NCCA in its Assessment for Learning Initiative, drowns out the whispers of other assessment discourse' (Looney, 2006, p. 352). Since then, the locus of assessment discourse has become a somewhat noisier place but the progress of reform in curriculum and assessment has been marked more by questions than answers. Nowhere, perhaps, is this more so than in the story of assessment policy and practice in junior cycle (students aged between 12-and 15-years of age). The story evolves as one of government policy intent on promoting a teacher-led, learningoriented assessment practice which has been actively resisted by the Irish post-primary teacher unions through their insistence that a centralized, externally-conducted assessment at this early stage of post-primary education is preferable to school-based, teacher-led assessments.

\section{Recent research on assessment in Ireland}

Looney and Klenowski (2008) argue that the focus in Ireland has been on curriculumrather than assessment-led reform as a driver of change in education. Since then, Irish assessment-related research has explored the enactment of assessment for learning (Lysaght, 2015), high-stakes tests in Ireland (Elwood, Hopfenbeck, \& Baird 2017), the impact of the OECD Programme for International Student Assessment (PISA) results on 
assessment practices (Kirwan, 2015) and assessment with respect to the changing assessment landscape through the introduction of the Junior Cycle Framework (Lenihan, Hinchion, \& Laurenson, 2016). There has been a noticeable increase in greater support and professional development in Ireland for the use of assessment in classrooms, such as report card templates, problem-solving in mathematics and assessment for key competences.

\section{The Junior Cycle Review}

In March 1999, the NCCA issued The Junior Cycle Review: Progress Report: Issues and Options for Development (NCCA, 1999). The review focused on two issues, one of which was whether the current assessment arrangements were appropriate to the curriculum aims and objectives. This raised an awareness of the need for a changed approach to capturing and reporting evidence of student achievement. The Review noted a number of consequences of an over-reliance on a terminal written exam paper, including (i) a mismatch between curriculum aims and objectives and assessment through the vehicle of the examination paper, (ii) no direct relationship between formative assessment and formal assessment for certification purposes, (iii) the likelihood that potential early school-leavers were not motivated by a terminal exam at the end of three years, and (iv) questioning the integrity of a Junior Certificate programme that relies on a terminal written examination as the main (or only) form of assessment.

Subsequently, the focus of NCCA work on classroom-based assessment from 2003-2005 centred on support for teachers and schools in using classroom-based assessment and in reporting to parents. The continuing review of junior cycle recognised that assessment had been a neglected area in the professional and in-career development of teachers. Through a focus on assessment for learning (AfL), it sought to expand the assessment literacy of teachers, in support of a move away from the identification of assessment with examinations and the perception that in the assessment role the teacher was primarily coaching for externally administered tests. Attention had now switched to school-based reporting on student achievement, and an important dimension of the initiative in AfL was the support it could offer teacher judgement for this purpose. Subsequent reports (NCCA, 2005a, 2005b) act as indicators of a 
fundamental shift in emergent assessment policy, i.e., from classroom-based assessment for certification, to classroom-based assessment in support of learning and reporting by the teacher/school.

\section{Framework(s) for Junior Cycle}

Building on the earlier document Towards a Framework for Junior Cycle - Innovation and Identity (NCCA, 2011), the most significant change introduced in the Framework for Junior Cycle (DES, 2012) is in the area of assessment. Towards a Framework envisioned a curriculum that would allow schools to design their own junior cycle programme to meet the needs and interests of their students. The framework promises fundamental improvement in the learning experiences of students through changes to curriculum and assessment, where the traditional Junior Certificate examination is replaced by a new school-based model of assessment:

\footnotetext{
School-based assessment emphasises both the process and the product of learning in school through the combination of students' work and final assessment. This approach will ensure that assessment takes place as close as possible to the point of learning. Final assessment at the end of a period of study has a role to play, but it will be just one element of a broader school-based approach to assessment (NCCA, 2011, p. 18).
}

\section{Conclusion}

The launch of the 2012 Framework for Junior Cycle contained the seeds of a dispute which has continued to confound the junior cycle reform agenda to the present day. The enduring point of contention has been assessment change. Given that assessment was such a significant lever for change in the preceding years, it is not surprising that reform in the area attracted and continues to attract such attention. Trade union opposition, which in subsequent years aggregated to itself other curriculum and non-curriculum issues and industrial relations concerns, effectively applied a compelling brake to the reform process. Change has continued but it has been contested at every point, initially by both unions and latterly by one. It is not difficult to characterise the exchanges that followed as a struggle between competing perspectives on rights and responsibilities when it came to describing what students should learn and by extension, what schools and teachers should teach. 


\section{References}

Department of Education and Skills (DES). (2012). A Framework for Junior Cycle. Dublin: DES.

Elwood, J., Hopfenbeck, T., \& Baird, J.A. (2017). Predictability in high-stakes examinations: students' perspectives on a perennial assessment dilemma. Research Papers in Education, 32(1), 1-17.

Kirwan, L. (2015). Mathematics curriculum in Ireland: The influence of PISA on the development of project maths. International Electronic Journal of Elementary Education, 8(2), 317-332.

Lenihan, R., Hinchion, C., \& Laurenson, P. (2016). A changing assessment landscape in Ireland: the place of oral language. English in Education, 50(3), 280-296.

Looney, A. (2006). Assessment in the Republic of Ireland. Assessment in Education: Principles, Policy \& Practice, 13(3), 345-53.

Looney, A., \& Klenowski, V. (2008). Curriculum and assessment for the knowledge society: Interrogating experiences in the Republic of Ireland and Queensland, Australia. Curriculum Journal, 19(3), 177-92.

Lysaght, Z. (2015). Assessment "for" Learning and "for" Self-Regulation. International Journal of Emotional Education, 7(1), 20-34.

National Council for Curriculum and Assessment (NCCA). (2011). Towards a Framework for Junior Cycle - Innovation and Identity. Dublin: NCCA.

National Council for Curriculum and Assessment (NCCA). (2005a). Interim report on the developmental initiative in assessment for learning in junior cycle. Dublin: NCCA.

National Council for Curriculum and Assessment (NCCA). (2005b). Assessment for Learning. Report on Phase 2 of the developmental initiative. Dublin: NCCA.

National Council for Curriculum and Assessment (NCCA). (1999). The Junior Cycle Review: Progress Report: Issues and Options for Development. Dublin: NCCA. 